\title{
Characterization and composition of heavy metals and persistent organic pollutants in water and estuarine sediments from Gao-ping River, Taiwan
}

\author{
Ruey-an Doong ${ }^{\mathrm{a}, *}$, Shih-hui Lee ${ }^{\mathrm{a}}$, Chun-chee Lee ${ }^{\mathrm{a}}$, Yuh-chang Sun ${ }^{\mathrm{a}}$, Shian-chee Wu ${ }^{\mathrm{b}}$ \\ ${ }^{a}$ Department of Biomedical Engineering and Environmental Sciences, National Tsing Hua University, 101, sec. 2, Kuang-Fu Road, Hsinchu 30013, Taiwan \\ ${ }^{\mathrm{b}}$ Graduate Institute of Environmental Engineering, National Taiwan University, 10670 Taipei, Taiwan
}

\begin{abstract}
The objective of this study was to determine the concentrations and possible sources of heavy metals and persistent organic pollutants (POPs) in water and estuarine sediments from Gao-ping River in order to evaluate the environmental quality of aquatic system in southern Taiwan. High concentrations of heavy metals including $\mathrm{Cr}, \mathrm{Zn}, \mathrm{Ni}, \mathrm{Cu}$ and As, ranging from 10.7 to $180 \mathrm{mg} / \mathrm{kg}$-dry weight (dw), were detected in sediments from Gao-ping River. When normalized to the principal component analysis (PCA), swinery and electroplating wastewaters were found to be the most important pollution sources for heavy metals. Of various organochlorine pesticide (OCP) residues detected, aldrin and total-hexachlorocyclohexane $(\mathrm{HCH})$ were frequently found in sediments. The total concentrations of OCPs were in the range $0.47-47.4 \mathrm{ng} / \mathrm{g}$-dw. Also, the total-HCH, total-cyclodiene, and total-dichlorodiphenyltrichloroethane (DDT) were in the range $0.37-36.3,0.21-19.0$, and $0.44-1.88 \mathrm{ng} / \mathrm{g}-\mathrm{dw}$, respectively. The polychlorinated biphenyl (PCB) concentrations in sediments from Gao-ping River ranged between 0.37 and $5.89 \mathrm{ng} / \mathrm{g}-\mathrm{dw}$. The PCB concentrations are positively correlated to the organic contents of the sediment particles. $\alpha-\mathrm{HCH}$ was found to be the dominant compound of $\mathrm{HCH}$ in the sediments, showing that long-range transport may be the possible source for the contamination of $\mathrm{HCH}$ in sediments from Gao-ping River. In summary, trace amounts of POPs in estuarine sediments from Gao-ping River were detected, showing that there still exist a wide variety of POP residues in the river sediments in Taiwan. These POP residues may be mainly from long-range transport and weathered agricultural soils, while heavy metal contamination is primarily from the swinery and industrial wastewaters.
\end{abstract}

(C) 2008 Elsevier Ltd. All rights reserved.

Keywords: Gao-ping River; Heavy metals; Persistent organic pollutants (POPs); Organochlorine pesticides (OCPs); Polychlorinated biphenyls (PCBs); Sediments

\section{Introduction}

Persistent organic pollutants (POPs) such as organochlorine pesticides (OCPs) and polychlorinated biphenyls (PCBs) and heavy metals are ubiquitous contaminants in different compartments of the environments (Hong et al., 1999; Doong et al., 2002a; Martin et al., 2003; Fu and $\mathrm{Wu}, 2005,2006)$. In spite of numerous countries having withdrawn the registered usage of POPs for many years,

\footnotetext{
${ }^{*}$ Corresponding author. Tel.: +886 3 5726785; fax: +886 35718649 .

E-mail address: radoong@mx.nthu.edu.tw (R.-a. Doong).
}

these man-made chemicals still persist at considerable levels worldwide (Cleemann et al., 2000; Feng et al., 2003; Verweij et al., 2004; Wurl and Obbard, 2005; Chau, 2006; Katsoyiannis, 2006). These compounds are generally generated by anthropogenic processes and can be introduced into the environments through various routes. Due to their toxic, mutagenic, and carcinogenic characteristics, these persistent compounds are considered to be hazardous to the biota and environments. Also, these compounds are strongly sorbed onto the surface of particles associated with the organic content of solid-phase matrix and can be deposited to the underlying sediments. Therefore, the 
investigation of POP concentrations in aquatic environments is needed to provide important information on anthropogenic impact on the environment and serve as an indicator of contaminant loading.

The input pathways of POPs into the river environments include discharge of domestic sewage and industrial wastewater, runoff from nonpoint sources, and direct dumping of wastes into the river. Although sediments do not constitute a direct measure of the degree of aquatic pollution, they offer an irreplaceable aid in reconstructing the historical inputs of POPs based on profile descriptions of contamination in core samples (Hendy and Peake, 1996; Chang and Doong, 2006). Although the residual levels of the chlorinated compounds in the environments have considerably declined in the past thirty years, recent work has depicted that the chlorinated pesticides could be found in the range $0.04-330 \mathrm{ng} / \mathrm{g}$-dry weight $(\mathrm{dw})$ in marine and river sediments collected from Asian countries (Sarkar et al., 1997; Hong et al., 1999; Doong et al., 2002b; Hartwell, 2004; Wurl and Obbard, 2005; Minh et al., 2007). Moreover, some OCPs such as hexachlorocyclohexane $(\mathrm{HCH})$, dichlorodiphenyltrichloroethane (DDT) and endosulfan are still used in some countries around the tropical and subtropical belts for agricultural and medicinal purposes (Rajendran et al., 2005). These compounds can be deposited into the sediments through long-range atmospheric transport (LRT), resulting in a high exposure to OCPs in the areas near the pollution sources.

In addition to the contamination of POPs in sediments from riverine and estuarine areas, the distribution of trace metals can be affected by anthropogenic inputs. Trace metals are distributed globally with a wide range of concentrations in sediments and biota. High concentrations of heavy metals in sediments from estuarine and coastal areas in Asian countries have also been reported (Choi et al., 2006; Chen et al., 2007; Ip et al., 2007). Trace metals can be recirculated in the aquatic environments via natural or anthropogenic processes and then back to the water bodies, resulting in deterioration of the water quality and longterm implication of human health and ecosystem (Fatoki and Mathabatha, 2001; Ip et al., 2007). The change in environmental conditions such as $\mathrm{pH}$, redox potential, naturally organic matters and sediment texture may affect the remobilization of metals from sediments (Guevara-Riba et al., 2004; Lager et al., 2005; Choi et al., 2006). The trace metals associated with coarse particles may deposit on the upstream area of the estuary, while dissolved trace metals and those associated with fine particles could be transported to downstream to the surrounding coastal area by physical transportation (Ip et al., 2007). More recently, Chen et al. (2007) investigated the distribution and accumulation of trace metals in sediments of Kaohsiung Harbor, Taiwan and found that the metal concentrations at the vicinity of river mouths were higher than those at other locations and metal concentrations correlated closely to the physicochemical properties of sediments. These results clearly show that the physical- and chemical properties of river basins and anthropogenic processes have significant influence on the fate and transport of trace metals in sediments.

The Gao-ping River is one of the important rivers for water supply and irrigation in southern Taiwan. It has a total length of $171 \mathrm{~km}$ with a catchment basin of $3257 \mathrm{~km}^{2}$, which is the largest catchment basin in Taiwan. Gao-ping River is also one of the most contaminated rivers in Taiwan. Approximately 500,000 tons of domestic and industrial wastewater, mainly from swinery wastewater, are discharged daily into the river. Two petrochemical industrial parks are located near the mouth of estuary and discharge 16,000 tons of wastewater daily into the river. Also, the average sand loading rate is $35.6 \times 10^{12}$ tons/year, mainly during the periods from June to October (Doong and Lin, 2004). This period is also the main flooding period of Gao-ping River, which can transport contaminant associated suspended particles from upstream to downstream. Moreover, Gao-ping River has been historically subjected to severe anthropogenic inputs of pollutants, such as heavy metals, total Kjeldahl nitrogen (TKN), total phosphorus (TP) and biochemical oxygen demand $\left(\mathrm{BOD}_{5}\right)$. Despite the potential for direct discharge of organic contaminants into the river, no measurement has been made for the content and composition of POPs and trace metals in Gao-ping River. Also, little is known regarding to the fate and potential sources of POPs and heavy metals in the aquatic environment of this region.

The objective of this study was to determine the concentrations and possible sources of POPs and trace metals in water and surface sediments from Gao-ping River in order to evaluate the pollution potential of river sediments in southern Taiwan. OCPs, PCBs and 8 metals including $\mathrm{Cr}, \mathrm{Cd}, \mathrm{Pb}, \mathrm{Ni}, \mathrm{Zn}, \mathrm{Cu}$, As and $\mathrm{Hg}$ were analyzed to characterize the distribution and fate of these compounds. Also, principal component analysis (PCA) was applied to the data in order to identify possible sources and the distribution of micropollutants.

\section{Materials and methods}

\subsection{Study area and sample collection}

The sampling stations are illustrated in Fig. 1. Twelve sampling stations along Gao-ping River and its tributary were selected. These sites locate from heavily contaminated $(\mathrm{K} 2, \mathrm{~K} 7$ and $\mathrm{K} 8$ ) to background areas (K12) in order to effectively monitor the distribution of pollution throughout the catchment basin of Gao-ping River. Surface sediment samples were collected using grab sampler. A total of 72 samples, including 36 water and 36 sediment samples, was collected in April, July and November 2000, which means that each station contained three water and three sediment samples. The water samples were directly collected from the river using $5 \mathrm{~L}$ pre-cleaned glass jars with polytetrafluoroethylene (PTFE) screw caps and $1 \mathrm{~L}$ plastic bottles for physicochemical parameter and heavy metal analyses, respectively. The glass jar was cleaned with bidis- 


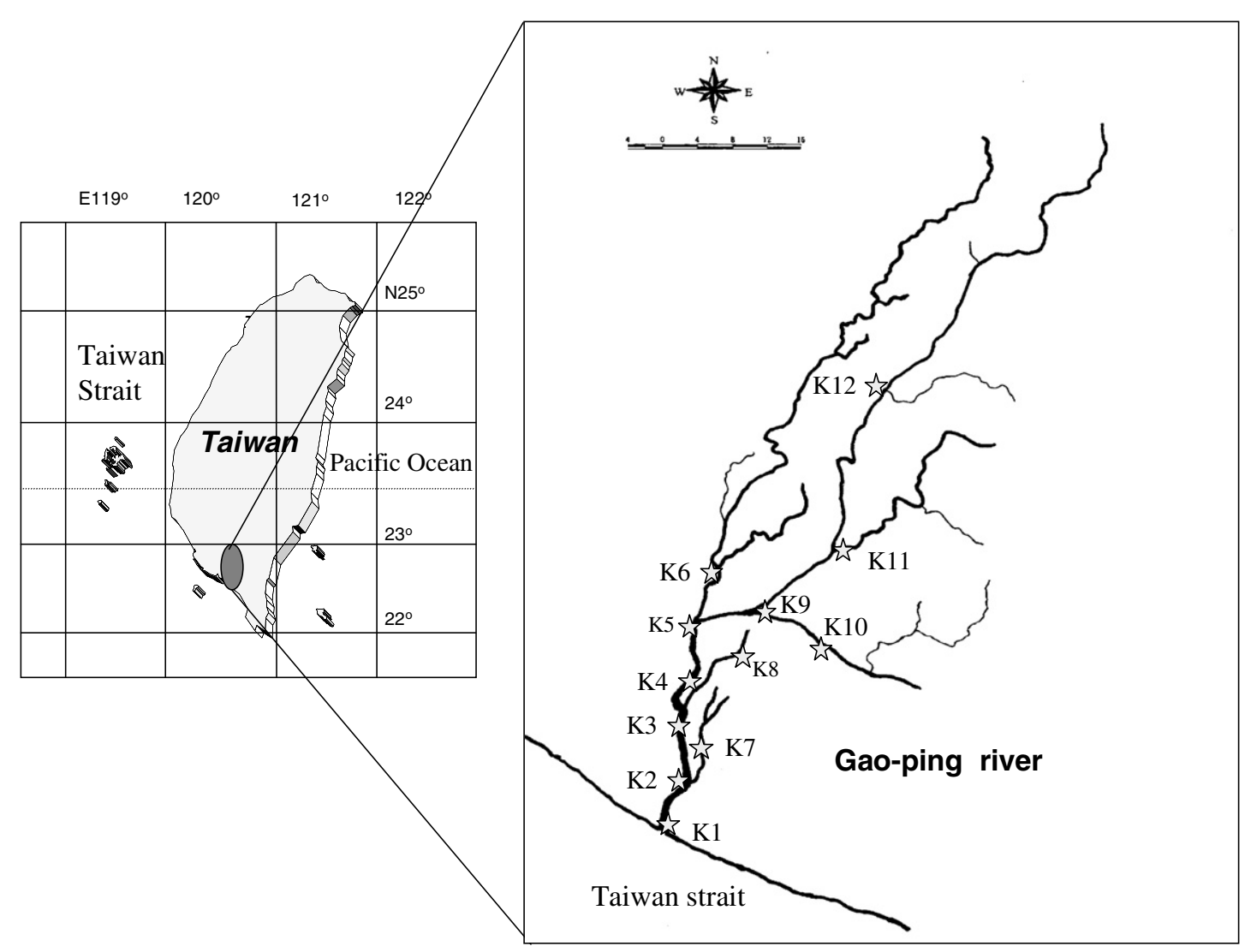

Fig. 1. The study areas and sampling locations in the Gao-ping River, Taiwan.

tilled water first, and then rinsed with methanol, acetone and hexane in sequence to remove trace amount of organic contaminants. Field blanks containing bidistilled water only were used to control the contamination during the sampling and transportation processes. The plastic bottle was washed with deionized water, immersed in 3\% nitric acid solution overnight, and then rinsed with bidistilled water. In addition, the sediment samples collected at each station were mixed and divided into three parts and were placed on ice after sampling, while the water samples for heavy metal analysis were acidified to $\mathrm{pH}<2$ using concentrated nitric acid. All the samples were transferred to the laboratory directly. The water samples were stored at $4{ }^{\circ} \mathrm{C}$ and analyzed within 2 weeks, while sediment samples were freeze-dried at $-18^{\circ} \mathrm{C}$ and analyzed within 1 month.

\subsection{Extraction and cleanup}

Homogenized subsamples were freeze-dried, and OCPs and PCBs were extracted with Soxhlet apparatus separately. A 10-gram sediment was placed into a thimble filter, and POP residues in sediments were extracted with $300 \mathrm{~mL} \mathrm{1:1}$ hexane/acetone for $24 \mathrm{~h}$ at a rate of $4-6 \mathrm{cycles} / \mathrm{h}$. The extracts were firstly preconcentrated to $2-3 \mathrm{~mL}$ on a rotary evaporator. Activated copper powder and tetrabutyl ammonium (TBA) solution were then used to remove sulfur compounds in PCB and OCP extracts, respectively. The 2-g Florisil solid-phase extraction (SPE) cartridges were used to cleanup both the PCB and OCP extracts. Sodium sulfate (ca. $1.0 \mathrm{~cm}$ ) was added to a Florisil SPE cartridge to remove trace amount of water in extracts. For OCP extracts, the cartridge was conditioned with $6 \mathrm{~mL}$ petroleum ether-ether $(95+5)$ at a rate of $5 \mathrm{~mL} / \mathrm{min}$, and then the OCPs in SPE cartridge were eluted with $12 \mathrm{~mL}$ petroleum ether-ether $(95+5)$ at a rate of $2 \mathrm{~mL} / \mathrm{min}$. For PCB extracts, the cartridge was activated with $10 \mathrm{~mL}$ hexane, and the PCBs were eluated with $10 \mathrm{~mL}$ ether-hexane $(6 \%, \mathrm{v} / \mathrm{v})$. All the elutes were concentrated to about $1-2 \mathrm{~mL}$ on a rotary evaporator, and then transferred to $10 \mathrm{~mL}$ glass tubes with small amounts of hexane. The solvent in the glass tube was entirely evaporated under a gentle stream of nitrogen and the precipitates were redissolved in $1 \mathrm{~mL}$ hexane and analyzed with a gas chromatograph-electron capture detector (GC-ECD) system.

The digestion for sediments was performed according to SW846 method 3052 (US EPA, 2004). The microwaveassisted digestion method was employed using PTFE digestion vessels (maximum pressure $200 \mathrm{psi}$ ) with pressure and temperature feedback control. An approximately $0.5 \mathrm{~g}$ of homogenized sediment was added into the mixture containing $9 \mathrm{~mL}$ nitric acid, $3 \mathrm{~mL}$ hydrochloric acid and $1 \mathrm{~mL}$ hydrofluoric acid, and then was transferred to digestion vessels. These vessels were then capped, sealed and heated in the microwave system with simultaneous temperature and pressure monitoring at $180^{\circ} \mathrm{C}$ for $10 \mathrm{~min}$. After the microwave digestion, the products were transferred to 
another PTFE beaker. The resultant solution was again heated in a class-100 clean bench until near dryness, and subsequently diluted to a known volume with bidistilled water and $1 \mathrm{~mL}$ nitric acid. Generally, the analytical errors due to the loss of analytes during the digestion process were evaluated by determining the spike recovery of heavy metals using an inductively coupled plasma mass spectrometer (ICP-MS) (Elan 5000, Perkin-Elmer Sciex, Norwalk, CT).

\subsection{Analytical procedures}

The concentrations of OCPs and PCBs in the extracts were monitored with GC-ECD. A PTE-5 capillary column $(30 \mathrm{~m} \times 0.32 \mathrm{~mm} \times 0.25 \mu \mathrm{m})$ and an SPB-608 capillary column $(30 \mathrm{~m} \times 0.25 \mathrm{~mm} \times 0.25 \mu \mathrm{m})$ were used for separating OCPs and PCBs, respectively. For OCPs, column temperature increased from $140{ }^{\circ} \mathrm{C}$ to $200^{\circ} \mathrm{C}$ at $15^{\circ} \mathrm{C} / \mathrm{min}$, held for $2 \mathrm{~min}$, and then programmed to $250^{\circ} \mathrm{C}$ at $2{ }^{\circ} \mathrm{C} / \mathrm{min}$, held for $2 \mathrm{~min}$. For PCBs, the initial temperature was set at $75^{\circ} \mathrm{C}$, held for $2 \mathrm{~min}$, and increased to $150^{\circ} \mathrm{C}$ at a rate of $15^{\circ} \mathrm{C} /$ min, held for $5 \mathrm{~min}$, programmed to $270{ }^{\circ} \mathrm{C}$ at a rate of $4^{\circ} \mathrm{C} / \mathrm{min}$, held for $5 \mathrm{~min}$, and then again ramped to $300{ }^{\circ} \mathrm{C}$ at a rate of $15^{\circ} \mathrm{C} / \mathrm{min}$, held for $5 \mathrm{~min}$. The temperatures of injector and detector were 250 and $310^{\circ} \mathrm{C}$, respectively. Ultra-high purity nitrogen gas was used as the carrier and make-up gases. Pentachloronitrobenzene and decachlorobiphenyl were used as the internal standards for OCPs. Compounds identified included $\mathrm{HCHs}(\alpha-\mathrm{HCH}$, $\beta-\mathrm{HCH}, \gamma-\mathrm{HCH}$ and $\delta-\mathrm{HCH}$ ), cyclodienes (heptachlor, aldrin, dieldrin, endrin, endosulfan I, endosulfan II and endosulfan sulfate) and DDTs ( $p, p^{\prime}$-DDT, $p, p^{\prime}$-DDD, $p, p^{\prime}-$ DDET and methoxychlor). For PCB analysis, mixtures of Aroclor $1242 / 1254 / 1260(1: 1: 1)$ were introduced as the quantification standard. Forty-two peaks (IUPAC No. 16, $18,28 / 31,33,41,48 / 47,49,52,66 / 95,56,70,83,92,101$, $97,99,110,105,118,128,135,138,141,146,149,151$, $153,158,163,170,171,174,177,180,183,185,187,194$, 195, 201 and 203) were identified and summarized as $\sum$ PCB. Decachlorobiphenyl was spiked into the sample before the extraction as a surrogate of the target compounds, and 2,4,6-trichlorobiphenyl was used as the internal standard for PCBs. Only peaks within the proper range $( \pm 2 \%)$ of the retention time when compared with the standards were counted for the quantification of PCB congeners (Fu and $\mathrm{Wu}, 2005,2006$ ). For every set of 10 samples, a procedural blank and spike sample consisting of all reagents was run to check for interference and cross-contamination. No obvious interference and contamination was observed during the analytical procedures.

The quality of the analytical data of OCPs and PCBs was assured using certified reference material (CRM 804050 soil standard) and standard reference material (NIST 1939a), respectively. Table 1 shows the recoveries and limits of detection (LODs) of OCPs in sediments. The LODs and recoveries of OCPs were in the range $0.05-0.35 \mathrm{ng} / \mathrm{g}$ $\mathrm{dw}$ and $82-120 \%$, respectively. In addition, the recoveries of OCPs in CRM samples ranged from 75 to $98 \%$. For
Table 1

The recoveries, limits of detection (LODs), and the analyzed results of CRM standards (840-050) of OCPs in sediments

\begin{tabular}{|c|c|c|c|c|}
\hline \multirow[t]{2}{*}{ Pesticides } & \multirow{2}{*}{$\begin{array}{l}\text { Recovery } \\
(\%)\end{array}$} & \multirow{2}{*}{$\begin{array}{l}\text { LODs } \\
\text { (ng/g-dw) }\end{array}$} & \multicolumn{2}{|c|}{ CRM standard $(\mu \mathrm{g} / \mathrm{kg})$} \\
\hline & & & $\begin{array}{l}\text { Certified } \\
\text { value }\end{array}$ & $\begin{array}{l}\text { Analyzed } \\
\text { value }\end{array}$ \\
\hline$\overline{\alpha-\mathrm{HCH}}$ & 99 & 0.12 & $-{ }^{\mathrm{a}}$ & - \\
\hline$\beta-\mathrm{HCH}$ & 106 & 0.35 & - & - \\
\hline$\gamma-\mathrm{HCH}$ & 99 & 0.22 & 491.4 & 414.7 \\
\hline$\delta-\mathrm{HCH}$ & 90 & 0.09 & - & - \\
\hline Aldrin & 92 & 0.05 & 18.04 & 14.6 \\
\hline Dieldrin & 99 & 0.12 & 1862.5 & 1467.7 \\
\hline Endrin & 82 & 0.22 & 62.15 & 54.3 \\
\hline Heptachlor & 101 & 0.15 & - & - \\
\hline Heptachlor epoxide & 95 & 0.24 & - & - \\
\hline Endosulfan I & 98 & 0.08 & 1464.3 & 1093.8 \\
\hline Endosulfan II & 91 & 0.16 & 1128.2 & 845.0 \\
\hline Endosulfan sulfate & 92 & 0.13 & - & - \\
\hline$p, p^{\prime}-\mathrm{DDD}$ & 109 & 0.18 & 1530.6 & 1278.1 \\
\hline$p, p^{\prime}-\mathrm{DDE}$ & 86 & 0.12 & 1519.6 & 1341.8 \\
\hline$p, p^{\prime}$-DDT & 120 & 0.18 & 1060.1 & 1042.1 \\
\hline Methoxychlor & 120 & 0.31 & - & - \\
\hline
\end{tabular}

${ }^{\mathrm{a}}$ Not available.

PCBs, the average recovery of the congeners in the SRM was $82 \pm 6 \%$ with the range of $73 \%(\mathrm{CB} 118)$ to $90 \%$ (CB138/163). The LODs were in the range 0.032 (CB44) to $0.088(\mathrm{CB} 18) \mathrm{ng} / \mathrm{g}-\mathrm{dw}$ with the recovery of $96 \pm 23 \%$ from spiked PCB standards, showing that the analytical protocols used in this study can effectively determine residues of POPs in sediments.

Trace metals $(\mathrm{Cr}, \mathrm{Cd}, \mathrm{Pb}, \mathrm{Ni}, \mathrm{Zn}, \mathrm{Cu}$ and $\mathrm{As})$ in digested sediment and filtrated water samples $(0.45 \mu \mathrm{m})$ were determined by ICP-MS with a cross-flow nebulizer and double pass spray chamber under Rf power of $1150 \mathrm{~W}$. In addition, cold vapor atomic absorption spectrometer (CVAAS) was used for $\mathrm{Hg}$ analysis. A CRM sample (NIST 2704 Buffalo river sediment) was used to assure the whole analytical and instrumental accuracy of the method. The LODs of heavy metals in water and sediment were in the range $0.037(\mathrm{~Pb})-0.99(\mathrm{Ni}) \mu \mathrm{g} / \mathrm{L}$ and $9.1(\mathrm{Cd})-249(\mathrm{As}) \mu \mathrm{g} / \mathrm{kg}-\mathrm{dw}$, respectively, with the recovery of $82-107 \%$. In addition, the recoveries of heavy metals in CRM samples ranged from $85 \%(\mathrm{Cr})$ to $121 \%(\mathrm{Hg})$.

Oxidation-reduction potential (ORP), volatile suspended solid (VSS), and water content in sediments were also analyzed. ORP was determined with an Orion EA 920 expandable ion analyzer (Orion Research Inc., Boston, MA.) by using an Orion model 97-78-00 Pt redox electrode. The values were expressed in terms of the ORP values of the samples relative to the $\mathrm{Pt}$ redox electrode, and were read out until the potential changed was less than $0.5 \mathrm{mV} / \mathrm{min}$. Water content and VSS were determined by the weight loss at $103 \pm 2{ }^{\circ} \mathrm{C}$ and $550 \pm 50^{\circ} \mathrm{C}$, respectively. Total organic carbon (TOC) concentrations of water samples were obtained by a model 700 TOC analyzer (O.I. Corporation, Texas). In addition, concentrations of TKN and TP in sediments were analyzed and determined according to "Standard Methods" (APHA, 1995). 


\section{Results and discussion}

\subsection{Characteristics of sediments}

The Gao-ping River is one of the highly polluted rivers in Taiwan. Table 2 illustrates the physicochemical parameters of sediments collected from Gao-ping River. These parameters included ORP, VSS, water content, TKN and TP concentrations. The ORP values ranged from 297 to $-388 \mathrm{mV}$, showing that the collected sediments were mainly under anaerobic conditions. Moreover, the VSS and water contents of the sediments ranged from $0.41 \%$ to $4.07 \%$ and from $19.1 \%$ to $70.6 \%$, respectively. The mean concentrations of TKN and TP in sediments were in the range $226-4524$ and $12-797 \mathrm{mg} / \mathrm{kg}-\mathrm{dw}$, respectively. It is noted that the concentrations of TKN and TP in the polluted locations (K1-K11) were 1.8-7.9 and 2.0-6.9 times higher than that detected from the background site (K12), which means that the nutrient pollution in Gao-ping River is serious. High concentrations of TKN and TP in sediment samples were found at stations $\mathrm{K} 2, \mathrm{~K} 7$ and $\mathrm{K} 8$. This may be attributed to the discharge of untreated industrial and swinery wastewaters into Gao-ping River. Sampling stations K7 and K8 are located on Niu-chou River and Wu-lo River, the highly polluted tributaries of Gaoping River. They receive about 100,000 tons of domestic and industrial wastewaters daily. The mean TOC concentrations in water samples at locations $\mathrm{K} 7$ and $\mathrm{K} 8$ were $3.83 \pm 1.32$ and $3.0 \pm 1.61 \mathrm{mg} / \mathrm{L}$, respectively. This value is two times higher than the average TOC content of the river $(1.79 \pm 0.83 \mathrm{mg} / \mathrm{L})$, showing that stations $\mathrm{K} 7$ and $\mathrm{K} 8$ are seriously polluted with micropollutants.

\subsection{Concentration profile of POP concentrations}

Table 3 illustrates the concentration ranges, mean values and detection frequencies of POP compositions in surface sediments. The detected concentrations of OCPs and PCBs in surface sediments from Gao-ping River were $<0.12$
$14.2 \mathrm{ng} / \mathrm{g}-\mathrm{dw}$ for $\alpha-\mathrm{HCH}, \quad<0.35-20.21 \mathrm{ng} / \mathrm{g}-\mathrm{dw}$ for $\beta$ $\mathrm{HCH},<0.22-15.1 \mathrm{ng} / \mathrm{g}-\mathrm{dw}$ for $\gamma-\mathrm{HCH},<0.09-1.14 \mathrm{ng} / \mathrm{g}-$ $\mathrm{dw}$ for $\delta-\mathrm{HCH}, \quad<0.15-0.93 \mathrm{ng} / \mathrm{g}-\mathrm{dw}$ for heptachlor, $<0.05-9.59 \mathrm{ng} / \mathrm{g}-\mathrm{dw}$ for aldrin, $<0.12-1.42 \mathrm{ng} / \mathrm{g}-\mathrm{dw}$ for dieldrin, $<0.22-0.97 \mathrm{ng} / \mathrm{g}-\mathrm{dw}$ for endrin, $<0.08-1.73 \mathrm{ng} / \mathrm{g}-$ $\mathrm{dw}$ for endosulfan I, $<0.16-1.22 \mathrm{ng} / \mathrm{g}-\mathrm{dw}$ for endosulfan II, $<0.13-3.45$ for endosulfan sulfate, $<0.12-0.73 \mathrm{ng} / \mathrm{g}-\mathrm{dw}$ for $p, p^{\prime}$-DDE, $<0.18-1.42 \mathrm{ng} / \mathrm{g}-\mathrm{dw}$ for $p, p^{\prime}-\mathrm{DDD},<0.18$ $1.88 \mathrm{ng} / \mathrm{g}-\mathrm{dw}$ for $p, p^{\prime}-\mathrm{DDT}, \quad<0.31-0.91 \mathrm{ng} / \mathrm{g}-\mathrm{dw}$ for methoxychlor and $0.38-5.89 \mathrm{ng} / \mathrm{g}-\mathrm{dw}$ for $\sum$ PCBs. The mean concentrations of individual POP in sediments were

Table 3

The concentration ranges, mean values and detection frequencies of OCPs and PCBs

\begin{tabular}{|c|c|c|c|c|c|c|}
\hline \multirow[t]{2}{*}{ POPs } & \multirow{2}{*}{$\begin{array}{l}\text { Range } \\
\text { (ng/g-dw) }\end{array}$} & \multirow{2}{*}{$\begin{array}{l}\text { Mean } \\
\text { value } \\
(\mathrm{ng} / \mathrm{g}-\mathrm{dw})\end{array}$} & \multicolumn{4}{|c|}{ Detection frequency $(\%)$} \\
\hline & & & $\begin{array}{l}\text { April } \\
2000\end{array}$ & $\begin{array}{l}\text { July } \\
2000\end{array}$ & $\begin{array}{l}\text { November } \\
2000\end{array}$ & $\mathrm{Me}$ \\
\hline$\alpha-\mathrm{HCH}$ & $<0.12-14.2$ & 1.63 & 42.9 & 35.7 & 42.8 & 40.5 \\
\hline$\beta-\mathrm{HCH}$ & $<0.35-20.21$ & 2.93 & 28.6 & 28.6 & 71.4 & 42.9 \\
\hline$\gamma-\mathrm{HCH}$ & $<0.22-15.01$ & 4.90 & 35.7 & 7.1 & 21.4 & 21.4 \\
\hline$\delta-\mathrm{HCH}$ & $<0.09-1.14$ & 0.50 & 7.1 & 28.6 & 21.4 & 19.0 \\
\hline Aldrin & $<0.05-9.59$ & 2.10 & 57.1 & 42.9 & 35.7 & 45.2 \\
\hline Dieldrin & $<0.12-1.42$ & 0.55 & 14.3 & 14.3 & & 11.9 \\
\hline Endrin & $<0.22-0.97$ & 0.45 & 7.1 & 35.7 & 42.8 & 28.5 \\
\hline Heptachlor & $.15-0.93$ & 0.55 & 50.0 & 7.1 & 7.1 & 21.4 \\
\hline Endosulfan I & $<0.08-1.73$ & 0.64 & 7.1 & 42.9 & 35.7 & 28.6 \\
\hline Endosulfan II & $<0.16-1.22$ & 0.49 & 7.1 & 14.3 & 28.6 & 16.7 \\
\hline $\begin{array}{l}\text { Endosulfan } \\
\text { sulfate }\end{array}$ & $<0.13-3.45$ & 1.24 & 21.4 & 78.6 & 0.0 & 33.3 \\
\hline$p, p^{\prime}$-DDE & $<0.12-0.73$ & 0.55 & 7.1 & 28.6 & 7.1 & 14.3 \\
\hline$p, p^{\prime}$-DDD & $<0.18-1.42$ & 0.72 & 50.0 & 21.4 & 7.1 & 26.2 \\
\hline$p, p^{\prime}$-DDT & $<0.18-1.88$ & 0.99 & 7.1 & 7.1 & 0.0 & 4.7 \\
\hline Methoxychlor & $<0.31-0.91$ & 0.87 & 7.1 & 7.1 & 0.0 & 4.7 \\
\hline$\sum \mathrm{OCPs}^{\mathrm{a}}$ & $0.12-47.4$ & 1.27 & 92.8 & 85.7 & 92.8 & 90.4 \\
\hline$\sum \mathrm{PCBs}^{\mathrm{b}}$ & $0.38-5.89$ & 1.43 & 83.3 & 91.7 & 83.3 & 86.1 \\
\hline
\end{tabular}

${ }^{a}$ Sum of $\alpha-\mathrm{HCH}, \beta-\mathrm{HCH}, \gamma-\mathrm{HCH}, \delta-\mathrm{HCH}$, heptachlor, aldrin, dieldrin, endrin, endosulfan I, endosulfan II, endosulfan sulfate, $p, p^{\prime}$-DDT, $p, p^{\prime}$ DDD, $p, p^{\prime}$-DDE and methoxychlor.

b Sum of 42 PCB congeners (IUPAC No. 16, 18, 28/31, 33, 41, 48/47, 49, $52,66 / 95,56,70,83,92,101,97,99,110,105,118,128,135,138,141,146$, $149,151,153,158,163,170,171,174,177,180,183,185,187,194,195,201$ and 203).

Table 2

Physio-chemical properties of sediments collected from different sampling locations along the Gao-ping River

\begin{tabular}{lllll}
\hline Stations & \multicolumn{3}{l}{ Physicochemical property $^{\mathrm{a}}$} & \\
\cline { 2 - 5 } & ORP $(\mathrm{mV})$ & VSS $(\%)$ & Water content $(\%)$ & TKN $(\mathrm{mg} / \mathrm{kg}-\mathrm{dw})$ \\
\hline K1 & -326 to -160 & $1.00-2.89$ & $37.3-43.1$ & $819-1531$ \\
K2 & -365 to -235 & $1.19-3.03$ & $32.4-70.6$ & $950-4524$ \\
K3 & -274 to -181 & $0.58-1.93$ & $28.3-36.9$ & $727-1223$ \\
K4 & -174 to -132 & $0.85-2.24$ & $33.7-42.7$ & $792-904$ \\
K5 & -187 to -180 & $0.66-1.77$ & $29.5-30.7$ & $563-836$ \\
K6 & -174 to -174 & $0.89-2.48$ & $28.8-41.6$ & $649-1148$ \\
K7 & -388 to -194 & $1.34-4.07$ & $39.4-58.3$ & $1803-4018$ \\
K8 & -298 to -198 & $1.10-2.80$ & $35.3-41.3$ & $1945-2720$ \\
K9 & -14 to 244 & $0.78-1.89$ & $28.5-41.8$ & $594-893$ \\
K10 & -196 to 297 & $0.47-1.36$ & $26.9-32.5$ & $399-1356$ \\
K11 & -178 to 275 & $0.41-1.27$ & $24.0-47.7$ & $310-1572$ \\
K12 & -64 to 244 & $0.79-1.90$ & $19.1-25.4$ & $226-521$ \\
\hline
\end{tabular}

a ORP: oxidation-reduction potential; VSS: volatile suspended solid; TKN: total Kjeldahl nitrogen; TP: total phosphorus. 
$0.50-4.90 \mathrm{ng} / \mathrm{g}-\mathrm{dw}$ for HCHs, $0.45-2.10 \mathrm{ng} / \mathrm{g}-\mathrm{dw}$ for cyclodienes, $0.55-0.99 \mathrm{ng} / \mathrm{g}-\mathrm{dw}$ for DDTs and $1.43 \mathrm{ng} / \mathrm{g}-\mathrm{dw}$ for $\sum$ PCBs (Table 3 ). In addition, the total concentrations of OCPs and PCBs in sediments ranged from 0.12 to $47.4 \mathrm{ng} / \mathrm{g}$-dw and from 0.38 to $5.89 \mathrm{ng} / \mathrm{g}-\mathrm{dw}$, respectively, with mean values of 1.27 and $1.43 \mathrm{ng} / \mathrm{g}$-dw.

The mean detection frequencies of OCPs in sediments varied from $4.7 \%$ to $45.2 \%$. Aldrin was the most often found OCP residues in sediments $(45.2 \%)$, followed by $\beta$ $\mathrm{HCH}(42.9 \%), \alpha-\mathrm{HCH}(40.5 \%)$, and endosulfan sulfate $(33.3 \%)$. The mean concentrations of aldrin, $\beta-\mathrm{HCH}, \alpha-$ $\mathrm{HCH}$ and endosulfan sulfate were $2.10,2.93,1.63$ and $1.24 \mathrm{ng} / \mathrm{g}-\mathrm{dw}$, respectively. However, several OCPs including dieldrin $(11.9 \%)$, endosulfan II $(16.7 \%), p, p^{\prime}$-DDE $(14.3 \%), p, p^{\prime}$-DDT $(4.7 \%)$ and methoxychlor $(4.7 \%)$ were only detected in a few sediment samples at low mean concentrations of between 0.49 and $0.99 \mathrm{ng} / \mathrm{g}$-dw. These results clearly depict that aldrin and $\mathrm{HCH}$ compounds were the predominant OCPs in sediments from Gao-ping River. Also, PCBs were frequently detected in the samples (83.3-91.7\%). Of the 42 PCB congeners detected, PCB18, PCB20, PCB28, PCB31, PCB41 and PCB70 were found to be the dominant species because of their relatively high concentrations in major portion of the sediment samples.

Table 4 compares the POP concentrations obtained in this study with the reported data in other Asian areas. Concentrations of $\sum$ cyclodiene were in the range $0.21-10.6 \mathrm{ng} /$ $\mathrm{g}-\mathrm{dw}$, which are comparable with those observed in Arabian Sea, India (Sarkar et al., 1997) and Wu-shi estuary, Taiwan (Doong et al., 2002b). Concentrations of $\sum \mathrm{HCH}$ in sediments from Gao-ping River varied from 0.37 to $36.3 \mathrm{ng} / \mathrm{g}-\mathrm{dw}$ with the mean value of $2.49 \mathrm{ng} / \mathrm{g}-\mathrm{dw}$. The lev- els of $\sum \mathrm{HCH}$ in this study were comparable with those in sediments collected from Haihe River, China (Yang et al., 2005), Minjiang River, China (Zhang et al., 2003), coastal regions of Singapore (Wurl and Obbard, 2005) and northern coast, Vietnam (Nhan et al., 1999), but higher than those in sediments of Pearl River estuary, China (Hong et al., 1999), Victoria Harbor, Hong Kong (Hong et al., 1995), Masan Bay, Korea (Hong et al., 2003) and Ulsan Bay, Korea (Khim et al., 2001). It is noted that the mean concentration of $\sum \mathrm{HCH}$ in Gao-ping River $(2.49 \mathrm{ng} / \mathrm{g}$ $\mathrm{dw})$ was lower than those in other locations (5.02$8.62 \mathrm{ng} / \mathrm{g}-\mathrm{dw}$ ) having similar contamination levels, depicting that the concentration of $\mathrm{HCH}$ in sediments from Gao-ping River is slightly high.

The levels of $\sum D D T$ and $\sum$ PCBs were in the range $0.44-1.88$ and $0.38-5.89 \mathrm{ng} / \mathrm{g}-\mathrm{dw}$, respectively, which are relatively low compared to those in sediments collected from other locations in Asian countries. The levels of $\sum D D T$ and $\sum$ PCBs in Gao-ping River were comparable with those obtained from Pearl River estuary, China (Hong et al., 1999) and Da-han River, Taiwan (Doong et al., 2002a). However, such concentrations were much lower than those in marine and estuarine sediments collected from India, Vietnam, Singapore, China and Hong Kong (Sarkar et al., 1997; Hong et al., 1999; Zhang et al., 2003; Wurl and Obbard, 2005; Yang et al., 2005). This result is reasonable because India and China are reported to be the largest DDT consumers in Asia (Rajendran et al., 2005). In addition, Wurl and Obbard (2005) investigated the POP concentrations in marine surface sediments collected from the coastline of Singapore and found that concentrations of $\sum D D T$ and $\sum$ PCBs were in the range

Table 4

Concentration and mean values of POP residues $(\mathrm{ng} / \mathrm{g}-\mathrm{dw})$ in sediments collected from various locations in Asian countries

\begin{tabular}{|c|c|c|c|c|c|c|c|c|c|}
\hline \multirow[t]{2}{*}{ Locations } & \multicolumn{2}{|c|}{$\sum \mathrm{HCH}(\mathrm{ng} / \mathrm{g}-\mathrm{dw})^{\mathrm{a}}$} & \multicolumn{2}{|c|}{$\begin{array}{l}\sum_{\mathrm{dw})^{\mathrm{a}}} \text { cyclodiene(ng/g- } \\
\end{array}$} & \multicolumn{2}{|c|}{$\sum D D T(n g / g-d w)^{a}$} & \multicolumn{2}{|c|}{$\sum$ PCBs (ng/g-dw) } & \multirow[t]{2}{*}{ References } \\
\hline & Range & Mean & Range & Mean & Range & Mean & Range & Mean & \\
\hline Gao-ping River, Taiwan & $0.37-36.3$ & 2.49 & $0.21-10.6$ & 0.86 & $0.44-1.88$ & 0.78 & $0.38-5.89$ & 1.43 & This study \\
\hline Pearl River estuary, China & $0.28-1.23$ & 0.68 & - & - & $1.36-8.99$ & 2.84 & $0.18-1.80$ & 0.67 & Hong et al. (1999) \\
\hline Haihe River, China & $1.88-18.8$ & 7.33 & - & - & $0.32-80.2$ & 15.9 & - & - & Yang et al. (2005) \\
\hline Minjiang River, China & $3.0-16.2$ & 8.62 & - & - & $1.5-13.0$ & 6.70 & $15.1-57.9^{\mathrm{c}}$ & 34.5 & Zhang et al. (2003) \\
\hline Victoria Harbor, HK & ND-2.3 & 0.58 & - & - & $1.38-25.4$ & 10.2 & $3.2-16.0$ & 8.90 & Hong et al. (1995) \\
\hline Nearshore, HK & $0.1-16.7$ & 5.02 & - & - & $0.27-14.8$ & 5.06 & $0.48-97.9^{\mathrm{d}}$ & 17.2 & Richardson and Zheng (1999) \\
\hline Arabian Sea, India & $0.85-7.87$ & - & $1.22-4.54^{\mathrm{b}}$ & - & $1.47-25.2$ & - & - & - & Sarkar et al. (1997) \\
\hline Ulsan Bay, Korea & $0.02-4.55$ & 0.59 & - & - & $0.05-43.4$ & 4.20 & - & - & Khim et al. (2001) \\
\hline Masan Bay, Korea & ND-1.03 & 0.61 & - & - & $0.28-89.2$ & 16.0 & $1.24-41.4$ & 15.0 & Hong et al. (2003) \\
\hline Coastal region, Singapore & $3.40-46.1$ & 18.1 & - & - & $2.2-11.9$ & 6.7 & $1.4-330^{\mathrm{e}}$ & 73.9 & Wurl and Obbard (2005) \\
\hline Wu-shi Estuary, Taiwan & $0.99-14.5$ & 3.99 & $0.46-13.0$ & - & ND-11.4 & 2.5 & - & - & Doong et al. (2002b) \\
\hline Da-han River, Taiwan & ND-2.08 & 0.39 & ND-4.51 & 1.05 & $0.06-2.91$ & 0.90 & - & - & Doong et al. (2002a) \\
\hline Northern Coast, Vietnam & $1.20-33.7$ & 8.53 & - & - & $6.2-10.4$ & 7.74 & $0.47-28.1^{\mathrm{f}}$ & - & Nhan et al. (1999) \\
\hline Mekong River delta, Vietnam & $<0.02-1.30$ & - & - & - & $<0.01-110$ & - & $0.039-9.2$ & 0.89 & Minh et al. (2007) \\
\hline
\end{tabular}

${ }^{\text {a }} \sum \mathrm{HCH}=\alpha-\mathrm{HCH}+\beta-\mathrm{HCH}+\gamma-\mathrm{HCH}+\delta-\mathrm{HCH} ; \sum$ cyclodiene $=$ heptachlor + aldrin + dieldrin + endrin + endosulfan $\mathrm{I}+$ endosulfan $\mathrm{II}+$ endosulfan sulfate; $\sum \mathrm{DDT}=p, p^{\prime}$-DDT $+p, p^{\prime}$-DDD $+p, p^{\prime}$-DDET + methoxychlor.

${ }^{\mathrm{b}}$ Only contain aldrin, dieldrin and endrin.

${ }^{c}$ Sum of 21 PCB congeners.

d in Aroclor $1242+1248+1254+1260$ (1:1:1:1) equivalents.

e Sum of 37 PCB congeners.

${ }^{\mathrm{f}}$ In Aroclor 1254 equivalents. 
2.2-11.9 and $1.4-330 \mathrm{ng} / \mathrm{g}-\mathrm{dw}$, respectively. These results clearly depict that contamination of DDTs and PCBs in sediments from Gao-ping River is low relative to the other Asian areas.

\subsection{Spatial and temporal distribution of POPS}

Fig. 2 illustrates the concentrations of POPs in surface sediments from Gao-ping River collected in different sampling seasons. High concentrations of $\sum \mathrm{OCPs}\left(\sum \mathrm{HCH}\right.$, $\sum$ cyclodiene and $\sum D D T$ ) ranging from 93.3 to $99.7 \mathrm{ng} /$ $\mathrm{g}$-dw in Gao-ping River were observed in the dry sampling seasons (April and November 2000), while low $\sum O C P$ concentration $(47.8 \mathrm{ng} / \mathrm{g}-\mathrm{dw})$ was detected in rainy season (July 2000). This distribution is similar to that in sediment from Wu-shi River, Taiwan (Doong et al., 2002b), and the dilution effect during the rainy season may account for the low concentration of OCPs. The contamination levels of $\sum \mathrm{HCH}$ in sediments from Gao-ping River were, in general, higher than those of $\sum$ cyclodiene and $\sum D D T$. However, the $\sum \mathrm{HCH}$ concentrations in sediments collected in July 2000 is lower than that of $\sum$ cyclodienes. It is noted that the $\sum \mathrm{HCH}$ concentration collected in the rainy season (July 2000) is also lower than those collected in the dry seasons (April and November 2000), while the levels of $\sum$ cyclodiene are similar. These results reflect the fact that the contamination sources and environmental fates of $\mathrm{HCHs}$ and cyclodienes may be different.

Fig. 3 illustrates the total concentration profiles of PCBs and OCPs from 12 sampling sites in Gao-ping River among different sampling seasons. The spatial distribution of OCPs was site-specific. High concentrations of $\sum \mathrm{OCPs}$ were found in sediments collected from locations $\mathrm{K} 1, \mathrm{~K} 2$, and K7. The total concentrations of OCPs were $0.48-18.3 \mathrm{ng} /$ g-dw at station $\mathrm{K} 1,1.19-33.7 \mathrm{ng} / \mathrm{g}-\mathrm{dw}$ at station $\mathrm{K} 2$, and $6.12-47.4 \mathrm{ng} / \mathrm{g}-\mathrm{dw}$ at station $\mathrm{K} 7$. These values were one order of magnitude higher than those in upstream region

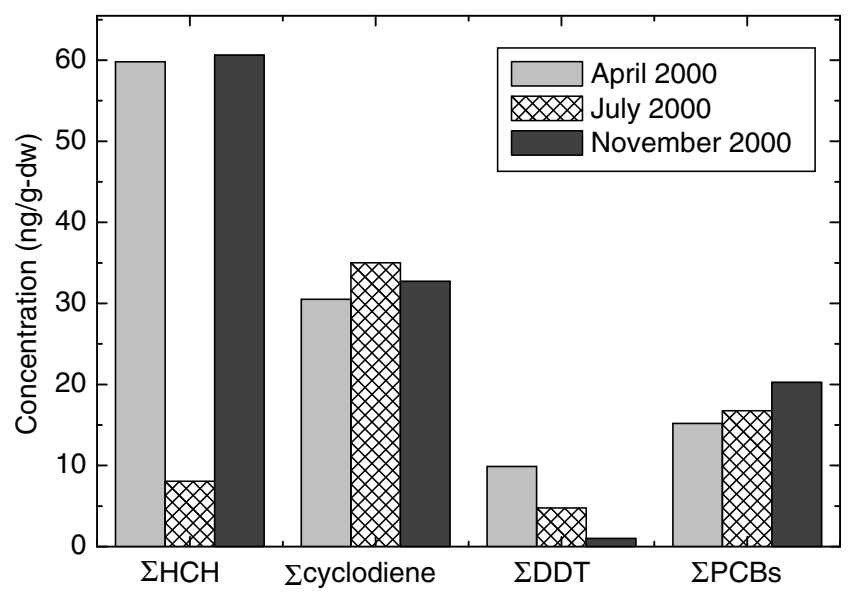

Fig. 2. The total concentrations of $\sum \mathrm{HCH}, \sum$ cyclodiene, $\sum \mathrm{DDT}$ and $\sum$ PCBs in sediments from Gao-ping River in different sampling seasons. The total concentrations of $\mathrm{HCH}$, cyclodiene and DDT are summed of each contaminant from all stations in one sampling period.
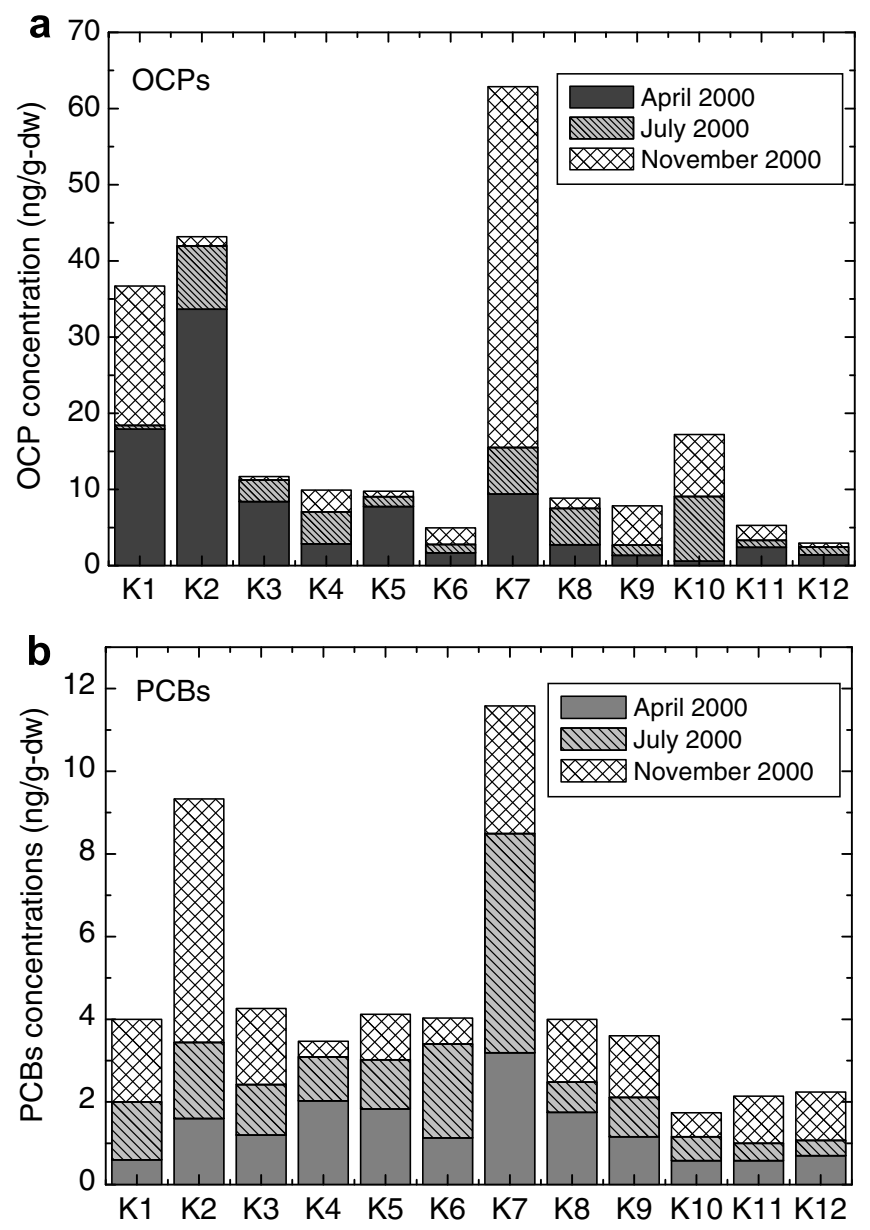

Fig. 3. The (a) OCP and (b) PCB concentrations in sediments from 12 sampling sites in Gao-ping River.

(K12). The highest contamination levels of $\sum \mathrm{HCH}$ at stations $\mathrm{K} 1, \mathrm{~K} 2$ and $\mathrm{K} 7$ can be up to $18.02,31.67$ and $36.22 \mathrm{ng} / \mathrm{g}-\mathrm{dw}$, respectively, showing that the contamination is mainly from HCHs. The total concentrations of OCPs collected in dry season were generally higher than that in rainy season. Similar results were also observed for PCBs. Relatively high concentrations of PCBs were measured at sampling sites of $\mathrm{K} 2$ and $\mathrm{K} 7$, which ranged from 1.60 to $5.89 \mathrm{ng} / \mathrm{g}-\mathrm{dw}$ and from 3.09 to $5.30 \mathrm{ng} / \mathrm{g}$-dw with the mean values of 3.11 and $3.86 \mathrm{ng} / \mathrm{g}-\mathrm{dw}$, respectively. These results are in accordance with the physicochemical properties of sediments (Table 2). Station K7 is located on the highly polluted tributary of Gao-ping River, while station K2 is located near the mouth of the estuary of Gao-ping River. The high concentrations of OCPs detected at stations K2 may be attributed to the emission of atmospheric deposits and the change in salinity of river water. Two big petrochemical industrial parks are located near the mouth of the Gao-ping River and discharge large amounts of wastewater into the river. The mixing of river water and seawater causes the change in salinity. Particles in river water can thus be rapidly removed by the flocculation in the estuarine mixing zone, leading to the accumulation of micropollutants in 
the sediments of estuary. In addition, High concentrations of $\sum \mathrm{OCP}$ and $\sum \mathrm{PCBs}$ in sediments samples were found at station $\mathrm{K} 7$. This result is in good agreement with those of TKN, TP and VSS (Table 2), which indicates that the contamination at $\mathrm{K} 7$ is attributed to the discharge of untreated industrial and swinery wastewater into Gao-ping River.

\subsection{Environmental fate of POPs in sediments}

The relative concentrations of the parent compound and its metabolite can provide useful information on the pollution source. DDT can be biodegraded by microorganisms to DDE and DDD under aerobic and anaerobic conditions, respectively. Therefore, ratios of (DDE + DDD)/ $\sum \mathrm{DDT}$ and DDE/DDD can be used as indicative indices for assessing the long-term weathering and biotransformation of DDT under various redox conditions, respectively (Zhang et al., 1999; Doong et al., 2002a; Wurl and Obbard, 2005; Yang et al., 2005). Fig. 4 illustrates the relationship between $(\mathrm{DDE}+\mathrm{DDD}) / \sum \mathrm{DDT}$ and DDE/DDD in surface sediments collected from Gao-ping River. Most values of DDE/DDD ratio were in the range 0.09-0.94, indicating that the collected samples were mainly under anaerobic conditions. These results are also in good agreement with the result of ORP values in sediments ( -388 to $297 \mathrm{mV}$ ). Moreover, the ratio of $(\mathrm{DDE}+\mathrm{DDD}) / \sum \mathrm{DDT}$ can be used to indicate the long-term weathering $(>0.5)$ or recent introduction of DDT compounds to the environments $(<0.5)$. Most ratios of (DDE + DDD)/ $\sum$ DDT ranged from 0.62-0.99, which means that the concentration of metabolites $(\mathrm{DDD}+\mathrm{DDE})$ is higher than that of parent compound (DDT), and the detected $\sum$ DDT concentrations may be derived from the aged and weathered agricultural soils.

Fig. 5 illustrates the composition profiles of $\mathrm{HCH}$ species in sediments from Gao-ping River. The $\mathrm{HCH}$ concentrations were summarized from the 12 sampling sites. The dominant isomers of $\mathrm{HCH}$ in sediments collected in April

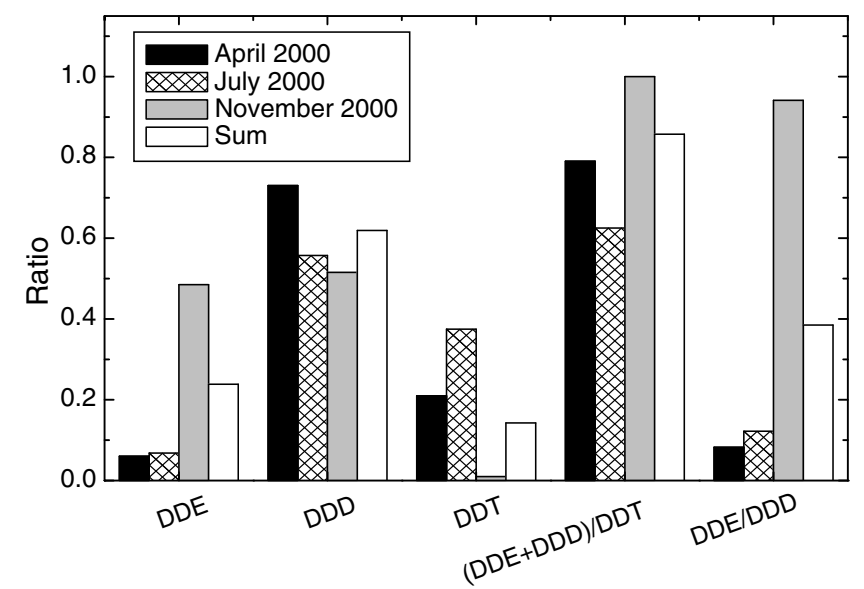

Fig. 4. The fractions of DDT compositions and the ratios of DDE/DDD and (DDE + DDD)/DDT in surface sediments collected from Gao-ping River.

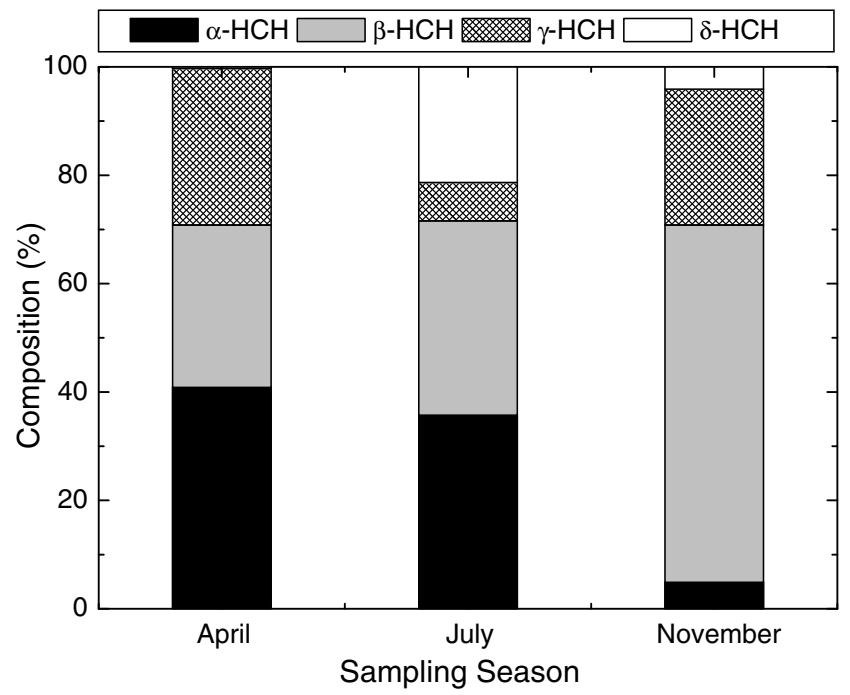

Fig. 5. The composition profiles of $\mathrm{HCH}$ species in sediments from Gaoping River.

and July 2000 were $\alpha$ - and $\beta-\mathrm{HCH}$, while $\beta$ - and $\gamma-\mathrm{HCH}$ were found as the dominant species collected in November 2000. Recent studies have shown that the contamination of $\mathrm{HCH}$ isomers is a serious problem worldwide (Fellin et al., 1996; Walker et al., 1999). HCH pesticide has been used for agricultural purpose to control the insects in fruit, grain and vegetable crops and is still used in some developing countries around the tropical belt. Among the $\mathrm{HCH}$ isomers, $\alpha-\mathrm{HCH}$ is more likely to partition to the air and transport for a long distance, while $\beta-\mathrm{HCH}$ is more resistant to hydrolysis and environmental degradation, and is the predominant isomer in soils and animal tissues and fluids. Recently, considerable unused stockpiles of technicalgrade $\mathrm{HCH}$ was found in dump sites in Africa and Near East (FAO, 1998). Some of the containers have been damaged and resulted in leakage. In this study, the most often found isomers are $\alpha$ - and $\beta$-isomers, inferring that the contamination of $\mathrm{HCH}$ in the collected sediments from Gaoping River may be attributed to the long-range transport and the erosion of the weathered agricultural soils containing $\mathrm{HCH}$ compounds.

\subsection{Concentration profiles of heavy metals}

Table 5 shows the range, mean and median concentrations of heavy metals in water and sediments from Gaoping River from 12 sampling sites. Most heavy metal concentrations in water samples were lower than those values of water quality standards promulgated by Taiwan Environmental Protection Administration (EPA). Although the mean value of $\mathrm{Cr}$ in water samples was lower than the water quality standards ( $50 \mu \mathrm{g} / \mathrm{L})$, some detected values in sampling locations $\mathrm{K} 7$ and $\mathrm{K} 8$ were higher than those of the water quality standards. It is noted that Gao-ping River is one of the major rivers for water supply in southern Taiwan. The high $\mathrm{Cr}$ concentration in Gao-ping River 
Table 5

The concentration range, mean values and median of heavy metals in water and sediment samples collected from Gao-ping River

\begin{tabular}{|c|c|c|c|c|c|c|c|}
\hline \multirow[t]{2}{*}{ Metals } & \multirow[t]{2}{*}{ Water quality standard ${ }^{\mathrm{a}}(\mu \mathrm{g} / \mathrm{L})$} & \multicolumn{3}{|c|}{ Water samples $(\mu \mathrm{g} / \mathrm{L})$} & \multicolumn{3}{|c|}{ Sediment samples (mg/kg-dw) } \\
\hline & & Range & Mean \pm SD & Median & Range & Mean \pm SD & Median \\
\hline $\mathrm{Cr}$ & 50 & $0.47-338$ & $19.2 \pm 63.4$ & 1.80 & $35.7-2714$ & $171 \pm 439$ & 57.5 \\
\hline $\mathrm{Cd}$ & 5 & $0.08-0.95$ & $0.25 \pm 0.22$ & 0.16 & $0.01-1.0$ & $0.21 \pm 0.23$ & 0.12 \\
\hline $\mathrm{Pb}$ & 50 & $0.77-13.8$ & $2.29 \pm 2.31$ & 1.77 & $18.3-92.9$ & $28.2 \pm 11.5$ & 24.9 \\
\hline $\mathrm{Cu}$ & 1000 & $0.90-34.3$ & $5.12 \pm 7.72$ & 2.49 & $14.5-197$ & $46.9 \pm 41.7$ & 32.8 \\
\hline $\mathrm{Ni}$ & 100 & $3.64-35.8$ & $7.54 \pm 6.14$ & 5.59 & $18.9-184$ & $38.6 \pm 26.4$ & 33.7 \\
\hline $\mathrm{Zn}$ & 5000 & $5.14-354$ & $29.6 \pm 56.3$ & 15.5 & $65.9-1535$ & $203 \pm 289$ & 122 \\
\hline As & 50 & $0.63-4.32$ & $2.29 \pm 0.97$ & 2.13 & $5.12-25.8$ & $11.3 \pm 3.94$ & 11.2 \\
\hline $\mathrm{Hg}$ & 2 & $<0.33$ & $<0.33$ & $<0.33$ & $0.20-1.72$ & $1.01 \pm 0.44$ & 1.11 \\
\hline
\end{tabular}

a Promulgated by Taiwan Environmental Protection Administration (EPA).

infers the possible hazard to human health. In addition, very high concentrations of trace metals were detected in sediments from Gao-ping River. Since Taiwan has not promulgated the sediment quality criteria (SQC) yet, the SQC in Hong Kong was used for comparison (Ip et al., 2007). It is surprised that the mean concentration of $\mathrm{Ni}$ has exceeded the trigger (B) level of the SQC in Hong Kong ( $35 \mathrm{mg} / \mathrm{kg}$ $\mathrm{dw})$. In addition, the mean concentrations of $\mathrm{Cr}$ and $\mathrm{Zn}$
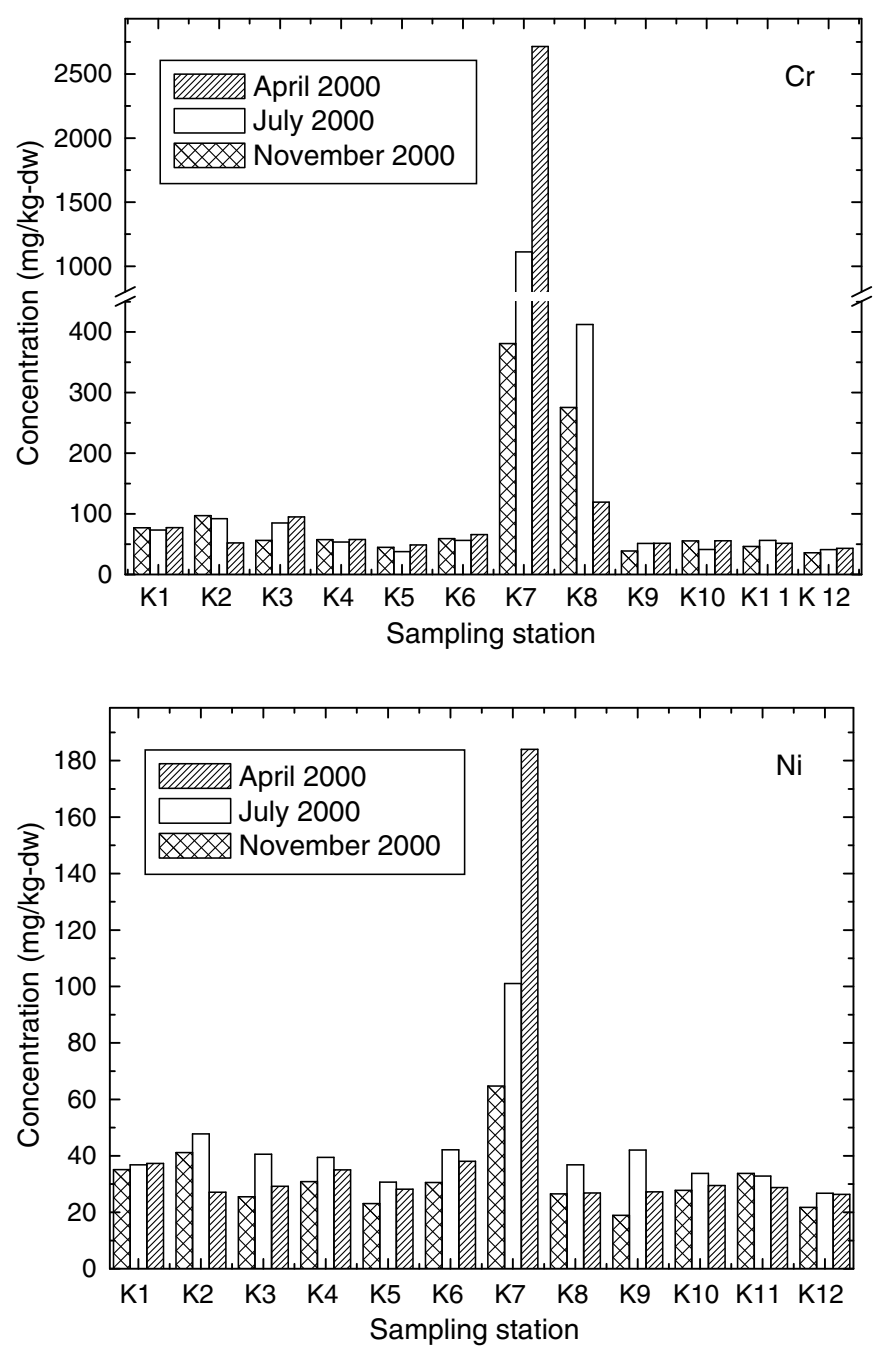

were $171 \pm 439$ and $203 \pm 289 \mathrm{mg} / \mathrm{kg}$-dw, respectively, which are much higher than the Action (C) level of SQC in Hong Kong $(80 \mathrm{mg} / \mathrm{kg}-\mathrm{dw}$ for $\mathrm{Cr}$ and $200 \mathrm{mg} / \mathrm{kg}-\mathrm{dw}$ for $\mathrm{Zn}$ ). These results clearly show that the sediments from Gao-ping River are highly contaminated with heavy metals.

Fig. 6 displays the site variations of the selected metal concentrations $(\mathrm{Cr}, \mathrm{Cu}, \mathrm{Ni}$ and $\mathrm{Zn})$ in sediments collected
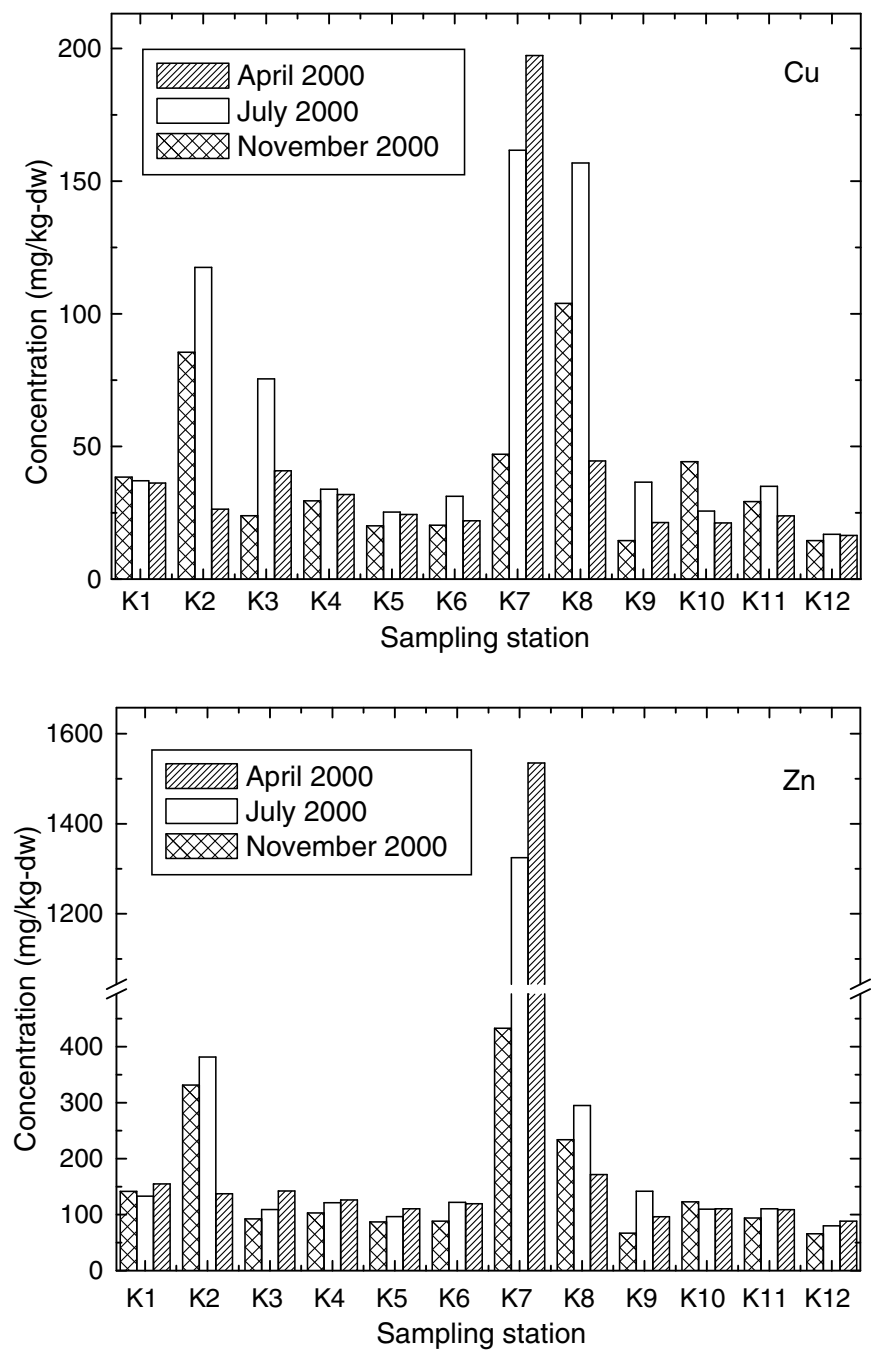

Fig. 6. The distribution of selected trace metals $(\mathrm{Cr}, \mathrm{Cu}, \mathrm{Ni}$ and $\mathrm{Zn})$ in sediments from 12 sampling sites in Gao-ping River. 
from 12 sampling sites in Gao-ping River. The detected concentrations from most sampling stations were, in general, similar to those of the background station (K12), which located in the upstream of Gao-ping River. It is noted that the metal concentrations $(\mathrm{Cr}, \mathrm{Cu}, \mathrm{Ni}$ and $\mathrm{Zn}$ ) detected from sampling locations $\mathrm{K} 2, \mathrm{~K} 7$ and $\mathrm{K} 8$ were higher than that of location $\mathrm{K} 12$, which is in good agreement with the distribution patterns of POPs. The high concentrations of trace metal detected at stations K2 may be attributed to the emission of atmospheric deposits and wastewater discharge from factories located near the mouth of the estuary of Gao-ping River and from the surface runoff of Kao-hsiung metropolitan, the biggest city located in the catchment of the Gao-ping River (Doong and Lin, 2004). The mixing of river water and sea water causing a change in salinity may be another possibility for the higher metal concentrations at location K2. Trace metals are usually associated with fine particles (Birch and Taylor, 2000; Singh et al., 2003). When fine particles move downstream to the mouth of Gao-ping River, the change in salinity enlarges the particle diameters by flocculation, resulting in the deposition of metal concentrations in the sediments of estuary.

High concentrations of trace metals in sediment samples were also found at stations $\mathrm{K} 7$ and $\mathrm{K} 8$. The mean concentrations of $\mathrm{Cr}, \mathrm{Cu}, \mathrm{Ni}$ and $\mathrm{Zn}$ at location $\mathrm{K} 8$ were $269 \pm 147,102 \pm 56,30.1 \pm 5.8$ and $234 \pm 62 \mathrm{mg} / \mathrm{kg}-\mathrm{dw}$, which are 2.5-6.0 times higher than that of the background station (K12). The contamination of sediments from sampling site $\mathrm{K} 7$ is more serious and the mean concentrations of trace metals were 2-3 orders of magnitude (29-104 times) higher than those from uncontaminated sites, presumably attributed to the discharge of untreated industrial and swinery wastewater into Gao-ping River.

\subsection{Principal component analysis}

The distribution patterns of heavy metals were analyzed by a principal component analysis (PCA). PCA is a multivariate statistical technique that can simplify large data sets and allow to reduce the number of variables to a smaller set of orthogonal factors of easier interpretation by displaying the correlations existing among the original variable (Ashley and Baker, 1999). This analysis was performed with the S-PLUS 2000 statistical software package. Due to the low residual concentration of POPs in sediments from Gaoping River, only trace metals and several physicochemical pollution indices including TKN, TP, water content, TOC and $\mathrm{BOD}_{5}$ were involved. In order to minimize the effect of absolute concentration on the first principal component, trace metals and pollution indices used for PCA analysis were normalized to the total amounts of the parameters (percent of total amount) (Woodhead et al., 1999).

The loading plot of PCA of trace metals in water samples from Gao-ping River is illustrated in Fig. 7a. Component 1 (PC1) can explain $42.71 \%$ of the total variance, with
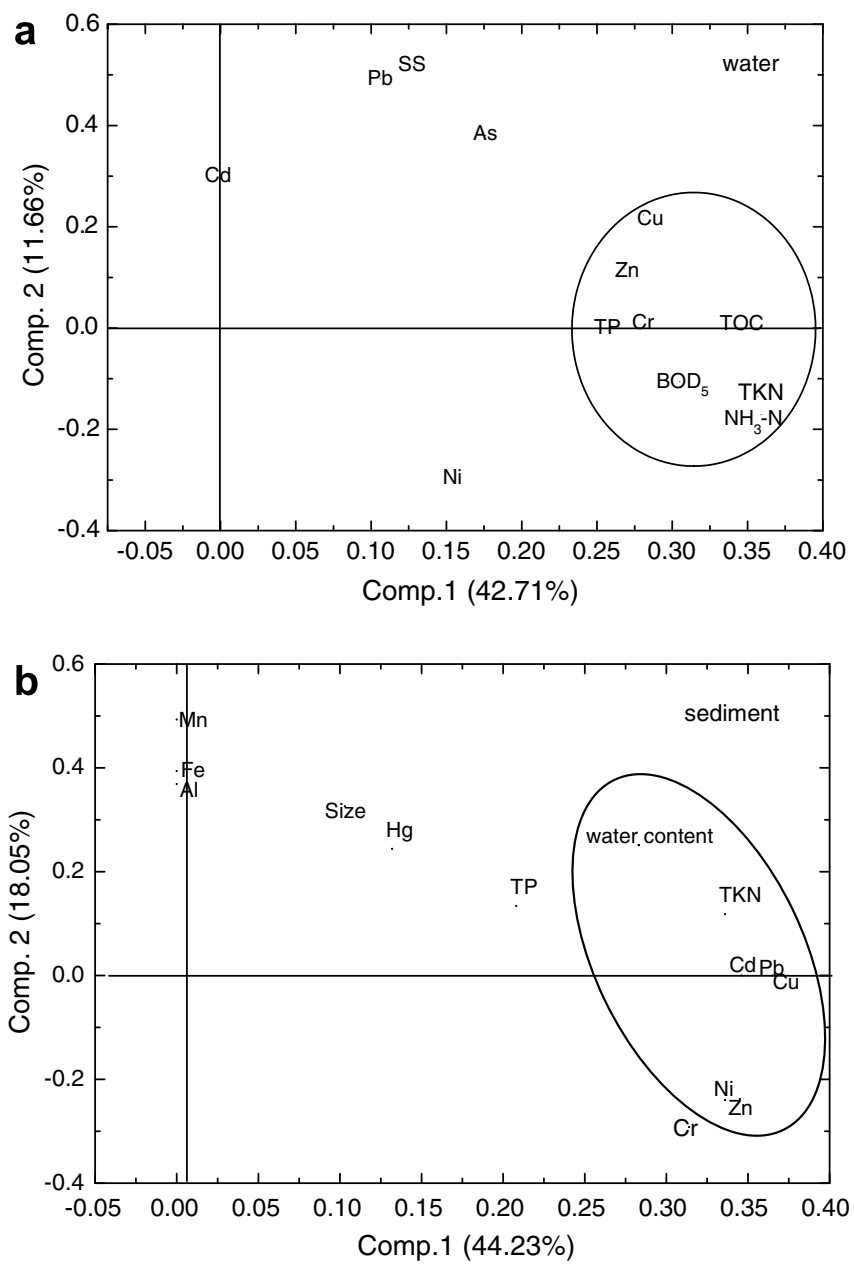

Fig. 7. The loading plot of principal component analysis (PCA) of (a) water and (b) sediments from Gao-ping River.

high loadings on TKN, TP, $\mathrm{BOD}_{5}$, TOC, and some trace metals $(\mathrm{Cr}, \mathrm{Cu}$ and $\mathrm{Zn})$. High loadings were observed at sampling locations $\mathrm{K} 7$ and $\mathrm{K} 8$, reflecting the high pollution potential on these sites. Since the pollution indices (TKN, $\mathrm{TP}$, and $\mathrm{BOD}_{5}$ ) and trace metals of $\mathrm{Cu}$ and $\mathrm{Zn}$ are highly related to the contamination of swinery wastewater (Ismail and Ramil, 1997), this result confirms that swinery wastewater is the main pollution source of Gao-ping River. Component 2 (PC2) can explain $11.7 \%$ of the total variance. High loadings on $\mathrm{Pb}, \mathrm{As}$ and particulates (SS) were observed, inferring that the mobility of $\mathrm{As}$ and $\mathrm{Pb}$ would be associated with particulates and could be moved easily downstream. From the distribution of sampling locations, high loadings of PCA were observed for stations K2 and $\mathrm{K} 4$ and $\mathrm{K} 5$, which are all located in the downstream of the main river. This also depicts that the major sources of the $\mathrm{Pb}$ and $\mathrm{As}$ contamination in aquatic environments are different from those of $\mathrm{Zn}$ and $\mathrm{Cu}$.

Similar to the results obtained in water samples, most of the total variances in the data set in sediment samples were accounted for by two principal components. As illustrated in Fig. $7 \mathrm{~b}, \mathrm{PCl}$ can explain $44.2 \%$ of the total variance, 

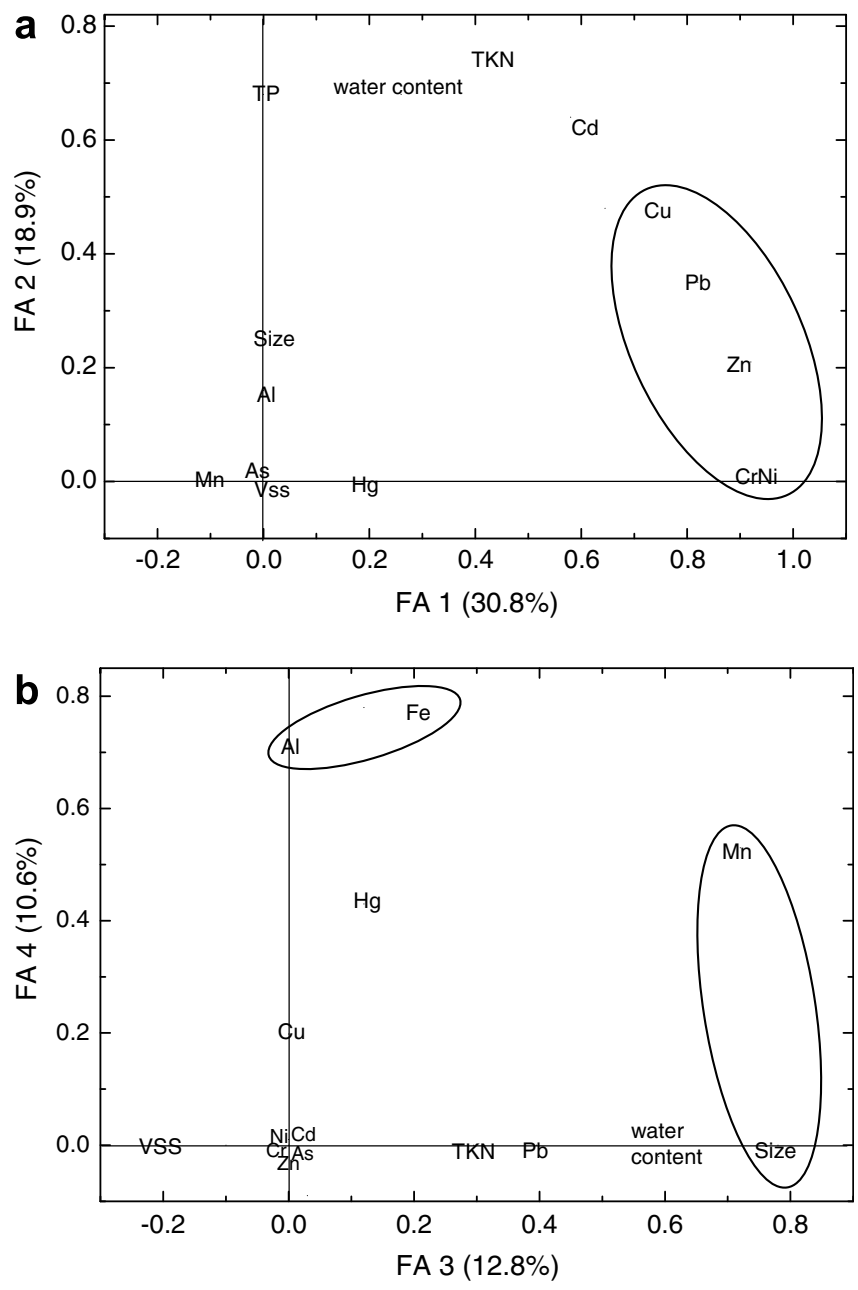

Fig. 8. The loading plot of factor analysis (FA) of sediment samples from Gao-ping River.

with the high loadings on water content, TKN, and most trace metals $(\mathrm{Cd}, \mathrm{Cr}, \mathrm{Ni}, \mathrm{Zn}$ and $\mathrm{Cu})$, which is in good agreement with the results obtained in water samples. PC2 can account for $18 \%$ of the total variance, with geochemical elements ( $\mathrm{Mn}, \mathrm{Fe}$ and $\mathrm{Al}$ ) as the abundant compounds. However, the characteristics of some pollution indices including grain size and $\mathrm{TP}$ are indistinguishable. Therefore, factor analysis (FA) was further employed.

Fig. 8 shows the factor analysis of trace metals and pollution indices in sediment samples from Gao-ping River. FA1 can explain $30.8 \%$ of the total variance with high loadings $(>0.7)$ on heavy metals $(\mathrm{Cu}, \mathrm{Pb}, \mathrm{Zn}, \mathrm{Cr}$ and $\mathrm{Ni})$. High loadings were observed for sampling location K7, reflecting that FA1 may be highly related to the pollution sources. It is noted that the major source of $\mathrm{Cu}$ and $\mathrm{Zn}$ is swinery wastewater, while the contamination of $\mathrm{Pb}, \mathrm{Ni}$ and $\mathrm{Cr}$ may result from the discharge of electroplating wastewater, showing that the serious contamination in Gao-ping River may mainly be due to the discharge of industrial and swinery wastewaters. FA2 can explain $18.9 \%$ of the total variance. High loadings on TP, TKN and water content were observed for sampling site K2, which reflects that FA2 represents the nutrient pollution. It is noted that this result is a little different from that in water sample, presumably due to that the trace metals are associated with particulates and deposited on the sediments, while the water soluble TP and TKN are easily moved downstream to the mouth of Gao-ping River (K2) by physical transportation. In addition, FA3 and FA4 can explain $12.8 \%$ and $10.6 \%$ of the total variance, respectively, with high loadings on geochemical elements and particle size, showing that these two factors represent the geochemical characteristics of Gao-ping River.

\section{Conclusions}

The results obtained in this study first document the compositions and distribution of heavy metals and POPs in sediments from Gao-ping River. The mean concentrations of TKN and TP in sediments ranged from 339 to 2650 and 134 to $624 \mathrm{mg} / \mathrm{kg}$, respectively. The VSS concentrations ranged between $0.99 \%$ and $2.74 \%$, clearing showing that the nutrient pollution in Gao-ping River is serious. In addition, there still exists trace amounts of OCPs and PCBs in estuarine sediments from Gao-ping River. The detected total concentrations of OCPs and PCBs were in the range of $0.12-47.4$ and $0.37-5.89 \mathrm{ng} / \mathrm{g}$, respectively, which are generally low to medium relative to the other Asian areas. $\mathrm{HCHs}$ and aldrin are the most abundant compounds in sediments. In addition, high concentrations of $\mathrm{Cr}, \mathrm{Cu}, \mathrm{Ni}$ and $\mathrm{Zn}$ in sediment samples were detected. The concentrations were 2-3 orders of magnitude higher than those of the uncontaminated sites. PCA analysis showed that the contamination of heavy metal is related to the pollution indices of the Gao-ping Rivers. The distribution patterns observed in this study reflects the fact that POP residues in surface sediments may be mainly from long-range transport and weathered agricultural soils, while the contamination of heavy metals is attributed to the discharge of industrial and swinery wastewaters into Gao-ping River.

\section{Acknowledgement}

The authors thank the National Science Council, Taiwan, ROC for the financial support under Contract No. NSC 95-2113-M-007-008.

\section{References}

American Public Health Association (APHA), 1995. Standard Methods for the Examination of Water and Wastewater. 19th ed., Washington, DC.

Ashley, J.T.F., Baker, J.E., 1999. Hydrophobic organic contaminants in surficial sediments of Baltimore harbor: inventories and sources. Environ. Toxicol. Chem. 18, 838-849.

Birch, G.F., Taylor, S.E., 2000. The use of size-normalized procedures in the analysis of organic contaminants in estuarine sediments. Hydrobiology 431, 129-133. 
Chang, S.M., Doong, R.A., 2006. Concentration and fate of persistent organochlorine pesticides in estuarine sediments using headspace solidphase microextraction. Chemosphere 62, 1869-1878.

Chau, K.W., 2006. Persistent organic pollution characterization of sediments in Pearl River estuary. Chemosphere 64, 1545-1549.

Chen, C.W., Kao, C.M., Chen, C.F., Dong, C.D., 2007. Distribution and accumulation of heavy metals in the sediments of Kaohsiung Harbor, Taiwan. Chemosphere 66, 1431-1440.

Choi, S.C., Wai, O.W.H., Choi, T.W.H., Li, X.D., Tsang, C.W., 2006. Distribution of cadmium, chromium, copper, lead and zinc in marine sediments in Hong Kong waters. Environ. Geol. 51, 455-461.

Cleemann, M., Rigetm, F., Paulsen, G.B., Klungsøyr, J., Dietz, R., 2000. Organochlorines in Greenland marine fish, mussels, and sediments. Sci. Total Environ. 245, 87-102.

Doong, R.A., Lin, Y.T., 2004. Characterization and distribution of polycyclic aromatic hydrocarbon contaminations in surface sediment and water from Gao-ping River, Taiwan. Water Res. 38, 1733-1744.

Doong, R.A., Sun, Y.C., Liao, P.L., Peng, C.K., Wu, S.C., $2002 \mathrm{a}$. Distribution and fate of organochlorine pesticide residues in sediments from the selected rivers in Taiwan. Chemosphere 48, 237-246.

Doong, R.A., Peng, C.K., Sun, Y.C., Liao, P.L., 2002b. Composition and distribution of organochlorine pesticide residues in surface sediments from the Wu-shi River estuary, Taiwan. Mar. Pollut. Bull. 45, 246253.

Food and Agriculture Organization of the United Nations (FAO), 1998. Inventory of obsolete, unwanted and/or banned pesticides. FAO, Rome, Italy, Document GCP/INT/650/NET.

Fatoki, O.S., Mathabatha, S., 2001. An assessment of heavy metal pollution in the East London and Port Elizabeth harbours. Water SA 27, 233-240.

Fellin, P., Barrie, L.A., Dougherty, D., Toom, D., Muir, D., Grift, N., Lockhart, L., Billeck, B., 1996. Air monitoring in the Arctic: results for selected persistent organic pollutant for 1992. Environ. Toxicol. Chem. 15, 253-261.

Feng, K., Yu, B.Y., Ge, D.M., Wong, M.H., Wang, X.C., Cao, Z.H., 2003. Organo-chlorine pesticide (DDT and $\mathrm{HCH}$ ) residues in the Taihu Lake Region and its movement in soil-water system. I. Field survey of DDT and $\mathrm{HCH}$ residues in ecosystem of the region. Chemosphere 50, 683-687.

Fu, C.T., Wu, S.C., 2005. Bioaccumulation of polychlorinated biphenyls in mullet fish in a former ship dismantling harbor: a PCB-contaminated estuary and nestled coastal fish farms. Mar. Pollut. Bull. 51, 932-939.

Fu, C.T., Wu, S.C., 2006. Seasonal variation of the distribution of PCBs in sediments and biota in a PCB-contaminated estuary. Chemosphere 62, $1786-1794$.

Guevara-Riba, A., Sahuquillo, A., Rubio, R., Rauret, G., 2004. Assessment of metal mobility in dredged harbour sediments from Barcelona, Spain. Sci. Total Environ. 321, 241-255.

Hartwell, S.I., 2004. Distribution of DDT in sediments off the central California coast. Mar. Pollut. Bull. 49, 299-305.

Hendy, E.J., Peake, BM., 1996. Organochlorine pesticides in a dated sediment core from Mapua, Waimea inlet, New Zealand. Mar. Pollut. Bull. 32, 751-754.

Hong, H., Xu, L., Zhang, L., Chen, J.C., Wong, Y.S., Wen, T.S., 1995. Environmental fate and chemistry of organic pollutants in the sediment of Xiamen and Victoria harbors. Mar. Pollut. Bull. 31, 229-236.

Hong, H., Chen, W., Xu, L., Wang, X., Zhang, L., 1999. Distribution and fate of organochlorine pollutants in the Pearl River Estuary. Mar. Pollut. Bull. 39, 376-382.

Hong, S.H., Yim, U.H., Shim, W.J., Oh, J.R., Lee, I.S., 2003. Horizontal and vertical distribution of PCBs and chlorinated pesticides in sediments from Masan Bay, Korea. Mar. Pollut. Bull. 46 (2), 244-253.

Ip, C.C.M., Xi, X.D., Zhang, G., Wai, O.W.H., Li, Y.S., 2007. Trace metal distribution in sediments of the Pearl River Estuary and the surrounding coastal area, South China. Environ. Pollut. 147 (2), $311-$ 323.

Ismail, A., Ramil, R., 1997. Trace metals in sediments and molluscs from an estuary receiving pig farms effluent. Environ. Technol. 18, 509-515.

Katsoyiannis, A., 2006. Occurrence of polychlorinated biphenyls (PCBs) in the Soulou stream in the power generation area of Eordea, northwestern Greece. Chemosphere 65, 1551-1561.

Khim, J.S., Lee, K.T., Kannan, K., Villeneuve, D.L., Giesy, J.P., Koh, C.H., 2001. Trace organic contaminants in sediment and water from Ulsan Bay and its vicinity, Korea. Arch. Environ. Contam. Toxicol. $40,141-150$.

Lager, T., Hamer, K., Schulz, H.D., 2005. Mobility of heavy metals in harbour sediments. An environmental aspect for the reuse of contaminated dredged sediments. Environ. Geol. 48, 92-100.

Martin, M., Richardson, B.J., Lam, P.K.S., 2003. Harmonisation of polychlorinated biphenyl (PCB) analyses for ecotoxicologucal interpretations of southeast Asian environmental media: what's the problem? Mar. Pollut. Bull. 46, 159-170.

Minh, N.H., Minh, T.B., Kajiwara, N., Kunisue, T., Iwata, H., Viet, P.H., Tu, N.P.C., Tuyen, B.C., Tanabe, S., 2007. Pollution sources and occurrences of selected persistent organic pollutants (POPs) in sediments of the Mekong Rive delta, South Vietnam. Chemosphere 67, 1794-1801.

Nhan, D.D., Am, N.M., Carvalho, F.P., Vieneuve, J.P., Cattini, C., 1999. Organochlorine pesticides and PCBs along the coast of north Vietnam. Sci. Total Environ. (237/238), 363-371.

Rajendran, R.B., Imagawa, T., Tao, H., Ramesh, R., 2005. Distribution of PCBs, HCHs and DDTs, and their ecotoxicological implications in Bay of Bengal, India. Environ. Int. 31, 503-512.

Richardson, B.J., Zheng, G.J., 1999. Chlorinated hydrocarbons contaminants in Hong Kong surficial sediments. Chemosphere 39 (6), 913 923.

Sarkar, A., Nagarajan, R., Chaphadkar, S., Pal, S., Singbal, S.Y.S., 1997. Contamination of organochlorine pesticides in sediments from the Arabian Sea along the west coast of India. Water Res. 31, 195-200.

Singh, M., Müller, G., Singh, I.B., 2003. Geogenic distribution and baseline concentration of heavy metals in sediment of the Ganges River, India. J. Geochem. Explor. 80, 1-17.

United State Environmental Protection Agency (US EPA), 2004. Test Methods for Evaluating Solid Waste, Physical/Chemical Methods. Washington DC. Available from: <http://www.epa.gov/sw-846/ main.htm>.

Verweij, F., Booij, K., Satumalay, K., van der Molen, N., van der Oost, R., 2004. Assessment of bioavailable PAH, PCB and OCP concentrations in water, using semipermeable membrane devices (SPMDs), sediments and caged carp. Chemosphere 54, 1675-1689.

Walker, K., Vallero, D.A., Lewis, R.G., 1999. Factors influencing the distribution of lindane and other hexachlorocyclohexanes in the environment. Environ. Sci. Technol. 33, 4373-4378.

Woodhead, R.J., Law, R.J., Matthiessen, P., 1999. Polycyclic aromatic hydrocarbons in surface sediments around England and Wales, and their possible biological significance. Mar. Pollut. Bull. 38 (9), 773-790.

Wurl, O., Obbard, J.P., 2005. Organochlorine pesticides, polychlorinated biphenyls and polybrominated diphenyl ethers in Singapore's coastal marine sediments. Chemosphere 58 (7), 925-933.

Yang, R.Q., Lv, A.H., Shi, J.B., Jiang, G.B., 2005. The levels and distribution of organochlorine pesticides (OCPs) in sediments from the Haihe River, China. Chemosphere 61, 347-354.

Zhang, G., Min, Y.S., Mai, B.X., Sheng, G.Y., Fu, J.M., Wang, Z.S., 1999. Time trend of BHCs and DDTs in a sedimentary core in Macao estuary, southern China. Mar. Pollut. Bull. 39, 326-330.

Zhang, Z.L., Hong, H.S., Zhou, J.L., Huang, J., Yu, G., 2003. Fate and assessment of persistent organic pollutants in water and sediment from Minjiang River Estuary, Southeast China. Chemosphere 52, 14231430. 